\title{
NEW HERMITE-HADAMARD TYPE INEQUALITIES FOR $(\alpha, m)$-CONVEX FUNCTIONS AND APPLICATIONS TO SPECIAL MEANS
}

\author{
WENBING SUN AND QIONG LIU
}

Abstract. In this paper, some new results involving the left-hand side of the Hermite-Hadamard type inequalities for the class of functions whose second derivatives in absolute value at certain powers are $(\alpha, m)$-convex functions are obtained. Some applications to special means of real numbers are also given.

Mathematics subject classification (2010): 26D15, 26 A51.

Keywords and phrases: Hadamard's inequality, $(\alpha, m)$-convex function, Hölder inequality, powermean inequality.

\section{REFERENCES}

[1] M. E. ÖZDEMIR, U. S. KIRMACI, Two new theorems on mappings uniformly continuous and convex with applications to quadrature rules and means, Appl. Math. Comput. 143, 269-274 (2003).

[2] U. S. KIRMACI, M. E. ÖZDEMIR, On some inequalities for differentiable mappings and applications to special means of real numbers and to midpoint formula, Appl. Math. Comput. 153 (2004) 36-368.

[3] C. E. M. PEARCE, J. PEČARIĆ, Inequalities for differentiable mappings with application to special means and quadrature formula, Appl. Math. Lett. 13 (2000) 51-55.

[4] E. Set, M. E. Özdemir, S. S. Dragomir, On the Hermite-Hadamard inequality and other integral inequalities involving two functions, J. Inequal. Appl. 2010, Article ID 148102 (2010).

[5] M. A. LATIF, Inequalities of Hermite-Hadamard type for functions whose derivatives in absolute value are convex with applications, Arab J. Math. Sci. 21 (1) (2015), 84-97.

[6] V. G. MineşAn, A generalization of the convexity, Seminar on Functional Equations, Approx. and Convex., Cluj-Napoca, Romania, 1993.

[7] M. K. Bakula, E. Neuman, J. PEČARIĆ And V. ŠImić, Hermite-Hadamard's inequalities for multivariate $g$-convex functions, Mathematical Inequalities and Applications 8, 2 (2005), 305-316.

[8] B. Micherda AND T. RAJBA, On some Hermite-Hadamard-Fejér inequalities for $(k, h)$-convex functions, Mathematical Inequalities and Applications 15, 4 (2012), 931-940.

[9] M. W. Alomari, M. Darus And U. S. Kirmaci, Some inequalities of Hermite-Hadamard type for $s$-convex functions, Acta Mathematica Scientia, (2011) 31B (4): 1643-1652.

[10] M. K. BAKula, M. E. ÖZdemir And J. PeČArić, Hadamard-type inequalities for $m$-convex and $(\alpha, m)$-convex functions, J. Inequal. Pure and Appl. Math. 9, (4), (2007), Article 96.

[11] E. Set, M. SARdari And M. E. Özdemir And J. Rooin, On generalizations of the Hadamard inequality for $(\alpha, m)$-convex functions, RGMIA Res. Rep. Coll. 12 (4) (2009), Article 4.

[12] M. E. ÖZdemir, A. O. AKDemir, ANd A. Ekinci, New Hadamard-type inequalities for functions whose derivatives are $(\alpha, m)$-convex functions, Tbilisi Mathematical Journal, 7 (2) (2014), pp. 61-72.

[13] Muhammad Amer Latif, Muhammad Shoaib, Hermite-Hadamard type integral inequalities for differentiable m-preinvex and $(\alpha, m)$-preinvex functions, Journal of the Egyptian Mathematical Society, (2015) 23, 236-241.

[14] M. E. Özdemir, M. Avci, H. Kavurmaci, Hermite-Hadamard-type inequalities via $(\alpha, m)$ convexity, Computers and Mathematics with Applications 61 (2011) 2614-2620.

[15] M. E. Özdemir, Cetin Yildiz, A. O. Akdemir And E. SET, On some inequalities for s-convex functions and applications, Journal of Inequalities and Applications, 2013, 2013:333. 